UDK 547.56:582.711.714

$582.711 .714: 581.45 / .47$

\title{
PHENOLIC CONTENT AND ANTIOXIDANT ACTIVITY OF CRATAEGUS MONOGYNA JACQ. AND CRATAEGUS MACROCARPA HEGETSCHW. LEAVES AND FRUITS EXTRACTS
}

\section{Sadržaj fenola i antioksidacijska aktivnost ekstrakata lišća i ploda Crataegus monogyna Jacq. i Crataegus macrocarpa Hegetschw.}

\author{
Azra Tahirović ${ }^{1}$, Neđad Bašić ${ }^{1}$
}

\begin{abstract}
Phenolic contents of methanolic extracts prepared from leaves and fruits of Crataegus monogyna Jacq. and Crataegus macrocarpa Hegetschw. were determined. The antioxidant capacity was assessed by DPPH, ABTS and FRAP assay. The results showed that leaves were richer in the content of phenols $\left(59.23-91.91 \mathrm{GAE} \mathrm{g}^{-1}\right)$, flavonoids (2.38 - $4.08 \mathrm{mg} \mathrm{QE} \mathrm{g}^{-1}$ and 5.24 - $8.9 \mathrm{mg} \mathrm{RE} \mathrm{g}^{-1}$ ), phenolic acids (33.40 -

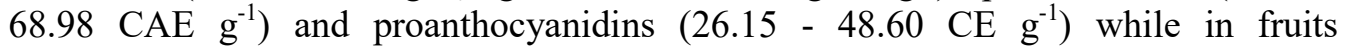
anthocyanins dominateted $\left(0.43-0.80 \mathrm{CG} \mathrm{g}^{-1}\right)$. Leaves also had higher antioxidant capacity than fruits for both species. Generelly, C. monogyna fruits had higher content of anthocyanins. Total phenols, phenolic acids and proanthocyanidins were highly corelated with DPPH $\left(r^{2}=0.8703-0.9618\right)$, ABTS $\left(r^{2}=0.7833-0.9443\right)$ and FRAP $\left(r^{2}=0.903-0.9695\right)$ assay. The results suggests that these compounds were the major contributors to the antioxidant capacity in leaves and fruits extracts of both species.

Higher contents of bioactive compounds and higher antioxidant capacity were determined for C. $x$ macrocarpa samples. Therefore, $C$. $x$ macrocarpa leaves and fruits are valuble source of antioxidant polyphenols with high potential for use in preparation of different natural health products.
\end{abstract}

Key words: C. monogyna, C. x macrocarpa, phenols, antioxidant capacity

\section{INTRODUCTION - Uvod}

Natural oxidants from fruits and vegetables have been studed for severel decedes in order to isolate compounds which can prevent or decrease different patological conditions assosiated with oxidative stress (cancer, heart deasese, atherosleroses, neuridegenerative desorders, diabiites, aging) (MANDEL ET AL., 2007; SEIFIRED ET AL., 2007; TEMPLE, 2000). Especially important group of natural antioxidants are phenols and studies showed their protective role against heart deases and cancer due to high antioxidant activity. The antioxidant activity of phenols is based on their redox properties and ability to scavenge wide range of reactive radical 
species. According to investigations in recent years the most important plant antioxidants are flavonoids and phenolic acids (OSAWA, 1994, RICE-EVANS ET AL., 1995).

The genus Crataegus belongs to Rosaceae family and it is represented by more than 200 species widespread in the Northen Hemisfere of Europe, Asia and America. Different plant parts (leaves, flowers, fruits) are used as cardiotonic, hypotensive, diuretic, antispasmodic and atherosclerotic agents (CHANG ET AL., 2002, ÖZCAN ET AL., 2005). Hawthorn leaves, flowers and fruits are rich source of different phenolic compounds with phenolic acids, flavones, flavonols and proanthocyanidins as the main active ingredients (CHANG ET AL., 2002; KIM ET. AL., 2000). It was found that hawthorn extracts possess antiradical activity (BERNATONIENE ET AL., 2008; BARROS ET AL., 2010; ZHANG ET AL., 2001).

Genus Crataegus in Bosnia and Herzegovina have been studied by several researches (BECK, 1927; MALY, 1919, 1940; FUKAREK 1974; JANJIĆ, 1998; BAŠIĆ, 2004, CHRISTENSEN AND JANJIĆ, 2006). One of the most abundant species of genus Crataegus in Bosnia flora is Crataegus monogyna Jacq with very wide ecological amplitude (BAŠIĆ, 2004). Since interspecies breedings are common in Crataegus this study included investigations on C. $x$ macrocapa a hybride between C. laevigata $x$. rhypidophylla. Presence of this hybride is well documented in Europe for a long time, and today is known under name C. $x$ macrocapa Hegetschw which was introduced for the first time by HRABĔTOVÁ-UHROVÁ (1969). This hybride specie is recently registreted in flora of Bosnia and Herzegovina (BAŠić, 2004).

Investigations of Crataegus species in terms of chemical composition and antioxidant activity have been started recently by our research group and they were focused mainly on C. monogyna and C. rhypidophylla from native populations around Sarajevo. According to our best knowledge this is the first paper on phenolic content and antioxidant activity of C. monogyna and C. x macrocarpa from Zenica region.

In this work we investigated phenolic contents and antioxidant activity of $\mathrm{C}$. monogyna and C. x macrocarpa leaf and fruit methanolic extracts. Obtained extracts were used in spectrophotometric determinations of total phenols, flavonoids, phenolic acids, monomeric anthocyanins and proanthocyanidins. Antioxidant activity for all extracts was investigated with three methods: DPPH, ABTS and FRAP using Trolox as a standard for expression of final results. Correlations between antioxidant capacities and different phenolic compounds were also investigated.

\section{MATERIAL AND METHODS - Materijal i metode}

\section{Plant material - Biljni materijal}

C. monogyna and C. x macrocarpa leaf and fruit samples were collected in October 2014. in Zenica region at locality of Smetovi. Two samples per species were collected from wider area and samples were identified by Prof Bašić, a plant taxonomist. Voucher specimens were deposited at the Herbarium of the Department of 
Ecology at Faculty of Forestry. The plant material was air-dried at room temperature and powdered before analysis.

\section{Chemicals and reagents - Hemikalije $i$ reagensi}

$$
\text { 1,1-diphenyl-2-picrylhydrazyl radical (DPPH), 2,2-azinobis(3- }
$$

ethylbenzothiazoline-6-sulphonic acid diammonium salt (ABTS), 2,4,6-tripyridil-Striazine (TPTZ), 6-hydroxy-2,5,7,8-tetramethylchroman-2-carboxylic acid (Trolox) as well as quercetin, rutin, gallic and caffeic acid, aluminium chloride, Folin-Ciocalteu's reagent, sodium carbonate and absolute methanol were purchased from Sigma Chemicals (Germany) and Aldrich (Germany).

Butanol was obtained from Merck Chemical Suppliers (Germany). Potassium chloride and ferrous ammonium sulfate were sourced from Kemika Zagreb (Croatia). All other chemicals and solvents were of analytical grade.

\section{Sample extracts preparation - Priprema ekstrakata uzoraka}

Leaf and fruit samples $(0.5 \mathrm{~g}$ each) were extracted twice in the extraction solvent containing $80 \%$ methanol $(12 \mathrm{~mL})$ with ultrasound bath, (Elmecs, Italy). Each extraction step was performed at room temperate for 30 minutes. Obtained supernatants for each sample were combined and collected in a volumetric flask and volume adjusted to $25 \mathrm{~mL}$ with extraction solvent. The extracts were kept at $-20^{\circ} \mathrm{C}$ until analysis.

\section{Determination of total phenols - Određivanje ukupnih fenola}

Procedure with Folin-Ciocalteu method described by SINGLETON ET AL. (1974) was used for the determination of total phenols (TP). The absorbance of the colored product was measured at $765 \mathrm{~nm}$. Appropriate calibration curve was prepared with gallic acid as standard, and final results are expressed as $\mathrm{mg}$ of gallic acid equivalents per gram of dry sample ( $\mathrm{mg} \mathrm{GAE}^{-1}$ ).

\section{Determination of total flavonoids - Odredivanje ukupnih flavonoida}

Colorimetric method with $\mathrm{AlCl}_{3}$ given by CHRIST AND MULLER (1960) and ABDENNACER ET AL. (2015) was used for the determination of total flavonoids. Briefly, sample aliquot $(0.5 \mathrm{~mL})$ was mixed with $1.5 \mathrm{~mL}$ methanol and $0.1 \mathrm{~mL}$ $\mathrm{CH}_{3} \mathrm{COONa}(1 \mathrm{M})$. Six minutes later, $0.1 \mathrm{~mL} \mathrm{AlCl} 3(10 \%)$ was added and dilution was made up to $5 \mathrm{~mL}$ with water. The solution was kept at room temperature for 30 minutes after that absorbance was measured at $430 \mathrm{~nm}$ against blank. Sample blanks were also included. Standard solutions of rutin and quercetin were used to prepare calibration curves. Final results for total flavonoids (TFq and TFr) are expressed as $\mathrm{mg}$ equivalents of quercetin/rutin per gram of dry sample ( $\mathrm{mg} \mathrm{QE} \mathrm{g}{ }^{-1}$ and $\mathrm{mg} \mathrm{RE} \mathrm{g}^{-1}$ ).

\section{Determination of total phenolic acids - Odredivanje ukupnih fenolnih kiselina}

Total phenolic acids (TPHA) were quantified with Arnov method described by GAWLIC-DZIKI (2012) with some modifications. One mililitre of appropriately 
diluted sample was mixed with $5 \mathrm{~mL}$ of water, $1 \mathrm{~mL} \mathrm{HCl}(0.5 \mathrm{M}), 1 \mathrm{~mL}$ of Arnov's reagent $\left(10 \mathrm{~g} \mathrm{Na}_{2} \mathrm{MoO}_{4}\right.$ and $10 \mathrm{~g} \mathrm{NaNO}_{2}$ dissolved in $100 \mathrm{~mL}$ of distillated water), 1 $\mathrm{mL}$ of $\mathrm{NaOH}(1 \mathrm{M})$ and the volume was made up to $10 \mathrm{~mL}$ with distillated water. Calibration curve was established with standard solutions of caffeic acid and apsorbance was measured at $490 \mathrm{~nm}$. Solvent instead of extract was used as a blank. The results are expressed as caffeic acid equivalents per gram of dry sample (mg CAE $\left.\mathrm{g}^{-1}\right)$.

\section{Determination of monomeric anthocyanins - Odredivanje monomernih antocijanina}

In the determination of total monomeric anthocyanins (TMA), $\mathrm{pH}$ differential method by LEE ET AL. (2005) was used Extracts were diluted in the ratio 1:10 and apsorbances were measured at 520 and $700 \mathrm{~nm}$ at room temperature after $15 \mathrm{~min}$. The content of total monomeric anthocyanins was expressed in $\mathrm{mg}$ of cyanidin-3-glucoside equivalents (CGE) per gram of dry fruits. A molar extinction coefficient of cyanidin3-O-glucoside of $269001 \mathrm{~mol}^{-1} \mathrm{~cm}^{-1}$ and molar weight (MW) (449.2 $\mathrm{g} \mathrm{mol}^{-1}$ ) were used for calculations.

\section{Determination of total proanthocyanidins - Odredivanje ukupnih proantocijanidina}

Total proanthocyanidins (TPA) were determined with butanol/ $\mathrm{HCl}$ assay (HAGERMAN, 2002). The method was based on their acid hydrolysis to anthocyanidins and color formation with the added reagent which is monitored spectrophotometrically. Absorbance of the sample was read at $550 \mathrm{~nm}$ before and after heating of the samples at $95^{\circ} \mathrm{C}$ for 40 minutes. Butanol/ $\mathrm{HCl}$ mixture was used as a blank. The results were expressed as $\mathrm{mg}$ of cyanidin chloride equivalents (CE) per gram of dry fruit.

\section{Determination of antioxidant capacity - Određivanje antioksidacijskog kapaciteta DPPH assay - DPPH esej}

DPPH assay was done according to BRAND-WILLIAMS ET AL. (1995) and THAIPONG ET AL. (2006). The method is based on the ability of standard and extracts to scavenge stable DPPH radical which leads to its decolonization and formation of yellow non-radical form. Stock solution of DPPH in methanol $(0.094 \mathrm{M})$ was freshly prepared and diluted with methanol to absorbance of $1.1 \pm 0.02$ at $515 \mathrm{~nm}$. After that, $100 \mu \mathrm{L}$ of previously diluted extracts was mixed with $1.9 \mathrm{~mL}$ of working DPPH solutions and kept in the dark for 30 minutes before measurements. Calibration curve was prepared with standard solutions of Trolox and the results are express in terms of Trolox equivalent antioxidant capacity (TEAC) as mmol Trolox equivalents per gram of dry sample weight.

\section{ABTS assay - ABTS esej}

ABTS assay was done according TO REE ET AL. (1999) with some modification given by THAIPONG ET AL. (2006). Basically it is a decolorisation assay which can be applied to lipophilic and hydrophilic antioxidants. In this assay radical 
monocation of 2,2-azinobis-(3-ethylbenzothiazoline-6-sulphonic acid) $\left(\mathrm{ABTS}^{\circ+}\right)$ is reduced with standard or extract. Stock solutions of ABTS $(7 \mathrm{mM})$ and potassium persulphate $(2.45 \mathrm{mM})$ were prepared in water and kept in the dark for 16 hours. Equal volumes of the stock solutions are mixed and diluted to absorbance of $1.1 \pm 0.02$ at $734 \mathrm{~nm}$ to prepare ABTS radical cation $\left(\mathrm{ABTS}^{\circ+}\right)$ solution. Freshly prepared solution was used for each assay. Working solution of $\operatorname{ABTS}^{*+}(1.9 \mathrm{~mL})$ was mixed with $100 \mu \mathrm{L}$ of previously diluted extracts and after 6 minutes the reduction in apsorbance was measured at $734 \mathrm{~nm}$. Calibration curve was prepared with standard solutions of Trolox and the results are express in terms of Trolox equivalent antioxidant capacity (TEAC) as mmol Trolox equivalents per gram of dry sample weight.

\section{FRAP assay - FRAP esej}

Ferric reducing antioxidant power (FRAP) was measured according to BENZIE AND STRAIN (1996) method. The method is based on reduction of ferric tripyridiyltriazine (Fe(III)-TPTZ) to ferrous trypyridyltriazine (Fe(II)-TPTZ) by sample extracts. As a result of reagent reduction, a blue product is formed which can be monitored spectrophotometrically. Briefly, FRAP reagent was prepared by mixing $300 \mathrm{mM}$ acetate buffer, $\mathrm{pH} 3.6 ; 10 \mathrm{mM} \mathrm{TPTZ}$ in $40 \mathrm{mM} \mathrm{HCl}$ acid and $20 \mathrm{mM} \mathrm{FeCl}_{3}$ in the ratio 10:1:1. The fresh working solution was wormed at $37^{\circ} \mathrm{C}$ before using. This reagent $(1.9 \mathrm{~mL})$ was mixed with $0.1 \mathrm{~mL}$ of the extracts and leaved in the dark for 30 minute before measurements. Apsorbance of the colored product was measured at 593 $\mathrm{nm}$ against the blank which contained $0.1 \mathrm{ml}$ of methanol instead of the extract. A standard curve was made with Trolox and the results were expressed as mmol Trolox equivalents per gram of dry sample weight.

\section{Statistical analysis- Statistička analiza}

All measurements were carried out in triplicate and obtained results are expressed as mean $\pm \mathrm{SD}$. Correlation between investigated active compounds and antioxidant activity was established by regression analysis.

\section{RESULTS AND DISCUSSION- Rezultati $i$ diskusija}

Phenolic compounds isolated from plant materials represent a reach source of natural antioxidants which receive much attention during last years. Flavonoids (flavonols, flavones and anthocyanins) show good antioxidant properties capable to scavenge free radicals (RICE-EVANS AND MULLER, 1997). Anthocyanins used as natural colorant becomes important due to their antioxidant and antibacterial properties (NAZ ET AL., 2007). Also, hydroxycinammic acids represent important class of phenolic compounds since they act as antioxidants in plant protection (CHEN AND HO, 1997). They are usually found at higher concentrations in plants (MANACH ET AL., 2004) and some of them such as caffeic acid can inhibite formation of mutagenic compounds in humans (OLTHOF ET AL., 2001). 
In this study we investigated contents of a range of bioactive compounds (phenols, flavonoids, phenolic acids, anthocyanins and proanthocyanidins) of $C$. monogyna and C. $x$ macrocarpa leaf and fruit methanolic extracts. Antioxidant capacity of the extracts was also examined with three methods: DPPH, ABTS and FRAP using Trolox as a standard. The results for quantitative contents of bioactive compounds for two investigated Crataegus species are presented in Table 1.

Table 1. Content of investigated polyphenolic compounds in extracts of C. monogyna and C. $x$ macrocarpa

Tabela 1. Sadržaj ispitivanih polifenolnih jedinjenja u ekstraktima C. monogyna $i$ C. $x$ macrocarpa

\begin{tabular}{|c|c|c|c|c|c|c|}
\hline Samples & $\begin{array}{c}\mathbf{T P} \\
\left(\mathrm{mg} \mathrm{GAEg}^{1}\right)\end{array}$ & $\begin{array}{c}\text { TFq } \\
\left(\mathrm{mg} \mathrm{QEg}^{-1}\right)\end{array}$ & $\begin{array}{c}\mathbf{T F r} \\
\left(\mathrm{mg} \mathrm{REg}^{-1}\right)\end{array}$ & $\begin{array}{l}\text { TPLA } \\
\left(\mathrm{mg} \mathrm{CAEg}^{-1}\right)\end{array}$ & $\begin{array}{c}\text { TPA } \\
\left(\mathrm{mg} \mathrm{CEg}^{-1}\right)\end{array}$ & $\begin{array}{c}\text { TMA } \\
\left(\mathrm{mg} \mathrm{CG} \mathrm{g}^{-1}\right)\end{array}$ \\
\hline \multicolumn{7}{|c|}{ C. monogyna } \\
\hline Leaf(1) & $59.23 \pm 0.13$ & $3.52 \pm 0.24$ & $7.70 \pm 0.53$ & $33.40 \pm 0.02$ & $26.15 \pm 0.69$ & $0.12 \pm 0.01$ \\
\hline Leaf(2) & $64.75 \pm 0.16$ & $2.38 \pm 0.02$ & $5.24 \pm 0.04$ & $39.41 \pm 0.03$ & $35.34 \pm 0.02$ & $0.09 \pm 0.004$ \\
\hline Average & 61.98 & 2.95 & 6.47 & 36.41 & 30.74 & 0.10 \\
\hline Fruit(1) & $25.01 \pm 0.06$ & $0.79 \pm 0.002$ & $1.76 \pm 0.01$ & $14.16 \pm 0.05$ & $12.00 \pm 0.02$ & $0.80 \pm 0.01$ \\
\hline Fruit(2) & $31.38 \pm 0.06$ & $0.31 \pm 0.01$ & $0.720 \pm 0.003$ & $17.94 \pm 0.03$ & $14.12 \pm 0.09$ & $0.44 \pm 0.01$ \\
\hline Average & 28.19 & 0.55 & 1.24 & 16.05 & 13.06 & 0.62 \\
\hline \multicolumn{7}{|c|}{ C. $x$ macrocarpa } \\
\hline Leaf(1) & $91.91 \pm 0.08$ & $3.24 \pm 0.01$ & $7.10 \pm 0.01$ & $68.98 \pm 0.14$ & $48.60 \pm 0.19$ & $0.27 \pm 0.04$ \\
\hline Leaf(2) & $72.98 \pm 0.36$ & $4.08 \pm 0.01$ & $8.90 \pm 0.02$ & $46.23 \pm 0.06$ & $37.61 \pm 0.15$ & $0.15 \pm 0.01$ \\
\hline Average & 82.44 & 3.66 & 7.99 & 57.60 & 43.11 & 0.21 \\
\hline Fruit(1) & $56.23 \pm 0.05$ & $0.74 \pm 0.01$ & $1.65 \pm 0.01$ & $37.49 \pm 0.05$ & $21.84 \pm 0.07$ & $0.67 \pm 0.01$ \\
\hline Fruit(2) & $40.97 \pm 0.53$ & $0.85 \pm 0.07$ & $1.81 \pm 0.02$ & $25.96 \pm 0.24$ & $15.02 \pm 0.02$ & $0.43 \pm 0.01$ \\
\hline Average & 48.60 & 0.79 & 1.65 & 31.72 & 18.43 & 0.55 \\
\hline
\end{tabular}

Total phenolic content (TP), total flavonoids/rutin content (TFr), total flavonoids/quercetin content (TFq), total phenolic acid (TPLA), total proanthocyanidins (TPA), total monomeric anthocyanins (TMA)

Sadržaj ukupnih fenola (TP), ukupnih flavonoida/rutin (TFr), ukupnih flavonoida/kvercetin (TFq), ukupnih fenolnih kiselina (TPLA), ukupnih proantocijanidina (TPA), ukupnih monomernih antocijanina (TMA)

Leaf and fruit extracts of $C$. monogyna were rich in phenolics, phenolic acids and proanthocyanidins. The average values in leaves were: phenols $61.98 \mathrm{mg} \mathrm{GAE} \mathrm{g}^{-1}$ DW, phenolic acids $36.41 \mathrm{mg} \mathrm{CAE} \mathrm{g}^{-1} \mathrm{DW}$, and proanthocyanidins $30.74 \mathrm{mg} \mathrm{CE} \mathrm{g}^{-1}$ DW. In fruits, avarage values were for phenols $28.19 \mathrm{mg} \mathrm{GAE}^{-1} \mathrm{DW}$, phenolic acids 
$16.05 \mathrm{mg} \mathrm{CAE} \mathrm{g}^{-1} \mathrm{DW}$, and proanthocyanidins $13.06 \mathrm{mg} \mathrm{CE} \mathrm{g}^{-1} \mathrm{DW}$. Avarage flavonoid content was 2.95 $\mathrm{QE} \mathrm{g}^{-1}$ and 6.47 RE g $\mathrm{g}^{-1} \mathrm{DW}$ for leaves and for fruits 0.55 $\mathrm{QE} \mathrm{g}^{-1}$ and 1.24 RE g ${ }^{-1} \mathrm{DW}$ (Table 1). According to the results of several studies given by EDWARDS ET AL. (2012) for C. monogyna fruits total phenols were in the range $9.1-17.8 \mathrm{mg} \mathrm{g}^{-1}$ and $16.42-57.07 \mathrm{mg} \mathrm{g}^{-1}$; total flavonoids $4.46-147 \mathrm{mg} \mathrm{g}^{-1}$, , and total proanthocyanidins 19.29 . $\mathrm{mg} \mathrm{g}^{-1}$. Also, leaves contained bioactive compounds in the following order: proanthocyanidins $32.83-53.48 \mathrm{mg} \mathrm{g}^{-1}$ and flavonoids $24.95-28.60$ $\mathrm{mg} \mathrm{g}^{-1}$. Results obtained in this work for flavonoids and proanthocyanidins in leaves and fruits are lower than the above mentioned which can be explained by different ecological conditions (climate, type of soil, exposore to the light) (BAHRI-SAHLOUL ET AL., 2009 A; LIU ET AL., 2005; BAHORUN ET AL., 1994).

Similarly to the results for C. monogyna, the most abundant compounds in of C. $x$ macrocarpa leaf and fruit were phenols, phenolic acids and proanthocyanidins. Average contents in leaves were for phenols $82.44 \mathrm{mg} \mathrm{GAE} \mathrm{g}^{-1} \mathrm{DW}$, phenolic acids 57.60 $\mathrm{CAE} \mathrm{g}^{-1} \mathrm{DW}$ and proanthocyanidins $43.11 \mathrm{mg} \mathrm{CE} \mathrm{g}^{-1} \mathrm{DW}$. In fruits, it was determined avarage content of phenols $48.60 \mathrm{mg} \mathrm{GAE} \mathrm{g}^{-1} \mathrm{DW}$, phenolic acids 31.72 CAE g ${ }^{-1}$ DW and proanthocyanidins $18.43 \mathrm{mg} \mathrm{CE} \mathrm{g}^{-1} \mathrm{DW}$ (Table 1). However, we could not find literature data to compare our results with the results of other investigators.

Generally, leaf extracts of $C$. monogyna had higher contents of investigated compounds than fruits except monomeric anthocyanins content $\left(0.10 \mathrm{mg} \mathrm{CG} \mathrm{g}^{-1} \mathrm{DW}\right.$ in leaves and $0.62 \mathrm{mg} \mathrm{CG} \mathrm{g}^{-1} \mathrm{DW}$ in fruits). ). This is in agreement with data given $\mathrm{BY}$ EDWARDS ET AL. (2012) for content of anthocyanins $\left(0.15-0.58 \mathrm{mg} \mathrm{g}^{-1}\right)$. Similar observations are found for C. $x$ macrocarpa leaf $\left(0.21 \mathrm{mg} \mathrm{CG} \mathrm{g}^{-1} \mathrm{DW}\right)$ and fruit extracts $\left(0.55 \mathrm{mg} \mathrm{CG} \mathrm{g}^{-1} \mathrm{DW}\right)$. Also, several studies concerning different plants confirmed that level of anthocyanins are higher in fruits than in leaves which is probably connected with coloration role of anthocyanins in fruits (ABDENNACER ET AL., 2015 AND REFERENCES THEREIN). Compering content of investigated compounds between two species we can conclude that C. $x$ macrocarpa leaves are richer in the content of phenols, flavonoids, phenolic acids, proanthocyanidins and anthocyanins while fruits of $C$. monogyna have only higher content of monomeric anhtocyanins.

Three different assays for the estimation of antioxidant capacity (AC) of plant extracts were used in this work. Since different reaction mechanisms can be involved in evaluation of antioxidant capacity two or more reactions are usually applied. In all cases, Trolox was used as a standard, and the results are expressed as Trolox equivalent antioxidant capacity (TEAC). Generally, the higher DPPH, ABTS and FRAP values point to greater antioxidant activity of the sample. Antioxidant activity of polyphenols is due to redox properties acting as a reducing agents, hydrogen donors and singlet oxygen quenchers (HANRAFI AND HAMRANI, 2010). The results are given in Table 2. 
Phenolic content and antioxidant actıvity of Crataegus monogyna Jacq. and Crataegus macrocarpa Hegetschw. Leaves and frutts extracts

Table 2. Antioxidant capacities of C. monogyna and C. $x$ macrocarpa leaves and fruits extracts Tabela 2. Antioksidacijski kapaciteti ekstrakata lišća i plodova C. monogyna i C. $x$ macrocarpa

\begin{tabular}{|c|c|c|c|}
\hline & $\begin{array}{c}\text { DPPH } \\
\left(\mathrm{mmol} \mathrm{Trolox} \mathrm{g}^{-1}\right)\end{array}$ & $\begin{array}{c}\text { ABTS } \\
\left(\mathrm{mmol} \mathrm{Trolox} \mathrm{g}^{-1}\right) \\
\end{array}$ & $\begin{array}{c}\text { FRAP } \\
\left({\left.\text { mmol Trolox } \mathrm{g}^{-1}\right)}\right.\end{array}$ \\
\hline \multicolumn{4}{|c|}{ C. monogyna } \\
\hline Leaf (1) & $0.34 \pm 0.035$ & $0.44 \pm 0.002$ & $0.378 \pm 0.001$ \\
\hline Leaf (2) & $0.37 \pm 0.001$ & $0.51 \pm 0.01$ & $0.45 \pm 0.01$ \\
\hline \multicolumn{4}{|l|}{ Average } \\
\hline & 0.36 & 0.47 & 0.41 \\
\hline Friut (1) & $0.12 \pm 0.001$ & $0.24 \pm 0.02$ & $0.17 \pm 0.01$ \\
\hline Fruit (2) & $0.11 \pm 0.01$ & $0.27 \pm 0.01$ & $0.19 \pm 0.002$ \\
\hline \multicolumn{4}{|l|}{ Average } \\
\hline & 0.11 & 0.25 & 0.18 \\
\hline \multicolumn{4}{|c|}{ C. $x$ macrocarpa } \\
\hline Leaf (1) & $0.48 \pm 0.06$ & $0.82 \pm 0.01$ & $0.57 \pm 0.004$ \\
\hline Leaf (2) & $0.44 \pm 0.01$ & $0.61 \pm 0.03$ & $0.44 \pm 0.01$ \\
\hline \multicolumn{4}{|l|}{ Average } \\
\hline & 0.46 & 0.72 & 0.50 \\
\hline Fruit (1) & $0.29 \pm 0.03$ & $0.531 \pm 0.0003$ & $0.40 \pm 0.01$ \\
\hline Fruit (2) & $0.22 \pm 0.01$ & $0.485 \pm 0.001$ & $0.25 \pm 0.01$ \\
\hline \multicolumn{4}{|l|}{ Average } \\
\hline & 0.26 & 0.51 & 0.32 \\
\hline
\end{tabular}

Antioxidant capacities determined with DPPH, ABTS and FRAP were higher for C. $x$ macrocarpa leaves and fruits samples than C. monogyna samples. Average values of antioxidant capacity found for $C$. monogyna leaves were DPPH $=0.36 \mathrm{mmol}$ Trolox g ${ }^{-1} \mathrm{DW}$, ABTS $=0.47 \mathrm{mmol}$ Trolox g ${ }^{-1} \mathrm{DW}$, and FRAP $=0.41 \mathrm{mmol}$ Trolox g ${ }^{-1}$ DW while for C. $x$ macrocarpa leaves were DPPH $=0.46 \mathrm{mmol}$ Trolox $\mathrm{g}^{-1} \mathrm{DW}$, ABTS $=0.72 \mathrm{mmol}$ Trolox $\mathrm{g}^{-1} \mathrm{DW}$, and FRAP $=0.50 \mathrm{mmol}$ Trolox $\mathrm{g}^{-1} \mathrm{DW}$ (Table 2). Fruits of both species had lower antioxidant capacity than leaves. Average values of antioxidant capacity found for C. monogyna fruits were $\mathrm{DPPH}=0.11 \mathrm{mmol}$ Trolox g ${ }^{-1}$ DW, ABTS $=0.25 \mathrm{mmol}$ Trolox $\mathrm{g}^{-1} \mathrm{DW}$, FRAP $=0.18 \mathrm{mmol}$ Trolox $\mathrm{g}^{-1} \mathrm{DW}$ while higher value were determined in C. $x$ macrocarpa fruits DPPH $=0.26 \mathrm{mmol}$ Trolox g ${ }^{-1}$ $\mathrm{DW}, \mathrm{ABTS}=0.51 \mathrm{mmol}$ Trolox $\mathrm{g}^{-1} \mathrm{DW}$, and FRAP $=0.32 \mathrm{mmol}$ Trolox $\mathrm{g}^{-1} \mathrm{DW}$ (Table 2). This can be explained with higher contents of all investigated compounds in C. $x$ macrocarpa leaves and fruits than C. monogyna samples. This is in agreement with several studies where it was found that antioxidant capacity of leaf extracts are higher than fruit extracts (ABDENNACER ET AL., 2015 AND REFERENCES THEREIN). We can also conclude that leaves and fruits of both Crataegus species have high antioxidant capacity. Values obtained for antioxidant capacity in this work for $C$. 
monogyna fruits are much higher than the values reported by RUIZ-RODRIGEZ ET AL. (2014) $\left(\right.$ TEAC $=1.54-7.11$ mmol Trolox $100 \mathrm{~g}^{-1}$ fresh weight $)$ and EGEA, ET AL. (2010) (TEAC ${ }_{\mathrm{ABTS}}=8.43 \mu \mathrm{mol}$ Trolox $\mathrm{g}^{-1}$ fresh weight). According to RUIZRODRIGEZ ET AL. (2014), AC for fresh fruits were in the range of $0.84-6.12 \mathrm{mmol}$ Trolox100 $\mathrm{g}^{-1}$ for ABTS assay; $0.76-2.03 \mathrm{mmol}$ Trolox $100 \mathrm{~g}^{-1}$ for DPPH assy, and 3.28 - 10.99 mmol Trolox $100 \mathrm{~g}^{-1}$ for FRAP assay. ÖZYÜREK ET AL. (2012) found that different variety of $C$. monogyna leaves in Turkey had $\mathrm{TEAC}_{\mathrm{ABTS}}$ in range 0.077 $0.330 \mathrm{mmol}^{\text {Trolox }} \mathrm{g}^{-1}$ and TEAC $\mathrm{FRAP}_{\mathrm{F}}$ in range $0.064-0.141 \mathrm{mmol}^{\mathrm{T}}$ Trolox $\mathrm{g}^{-1}$ which is lower than values obtained in this work (Table 2). Also, very similar values of AC for DPPH i FRAP method were obtained for all investigated samples while AC values for ABTS were higher. They were in the following order: ABTS $>$ FRAP $>$ DPPH. Similar results were obtained for guava fruits extracts which is explained with differences in the ability of antioxidant compounds to reduce DPPH, ASBTS and FRAP reagents (THAIPONG ET AL., 2006). It is also reported that stereoselectivity of the reagents as well as solvent used for extractions can be important factors influencing on scavenging effect of plant extracts (YU ET AL., 2002). Lower results for FRAP assay can be the results of uncomplete reaction of the reagent with flavonoids and phenolic acids (BERKER ET AL., 2007).

Linear regression was used to establish correlation coefficients between contents of bioactive compounds and antioxidant capacities. The obtained results are presented in Table 3.

Table 3. Correlation coefficients between phenolic compounds and DPPH, ABTS and FRAP assay.

Tabela 3. Korelacijski koeficijenti između fenolnih jedinjenja i DPPH, ABTS i FRAP eseja

\begin{tabular}{cccc}
\hline & \multicolumn{2}{c}{ Correlation coefficient $\left(\mathbf{r}^{2}\right)$} \\
\hline $\begin{array}{c}\text { Phenolic } \\
\text { Compounds }\end{array}$ & DPPH & ABTS & FRAP \\
\hline Phenols & $\mathbf{0 . 9 6 1 8}$ & $\mathbf{0 . 8 9 4 9}$ & $\mathbf{0 . 9 6 9 5}$ \\
\hline Flavonoids(Q) & 0.7302 & 0.4087 & 0.5477 \\
\hline Flavonoids (R) & 0.7301 & 0.4066 & 0.5499 \\
\hline Phenolic acids & $\mathbf{0 . 8 7 0 3}$ & $\mathbf{0 . 9 4 4 3}$ & $\mathbf{0 . 9 2 1 6}$ \\
\hline Proanthocyanidins & $\mathbf{0 . 8 9 5 3}$ & $\mathbf{0 . 7 8 3 3}$ & $\mathbf{0 . 9 0 3}$ \\
\hline Anthocyanins & 0.4845 & 0.2368 & 0.3737 \\
\hline
\end{tabular}

Very high correlations were noticed between DPPH, ABTS and FRAP and contents of phenols, phenolic acids, and proanthocyanidins. Correlation coefficients for phenolic content and DPPH, ABTS, FRAP assay were 0.9618; 0.8949, 0.9695 respectively. Strong correlations showed ABTS $\left(r^{2}=0.9443\right)$, FRAP $\left(r^{2}=0.9216\right)$ and DPPH method $\left(\mathrm{r}^{2}=0.8703\right)$ with phenolic acid content. Also, strong correlations were observed between proanthocyanidins and DPPH $\left(\mathrm{r}^{2}=0.8953\right)$, FRAP $\left(\mathrm{r}^{2}=0.903\right)$ and 
ABTS $\left(r^{2}=0.7833\right)$. High correlations were also noticed between antioxidant capacity with DPPH and flavonoid content $\left(\mathrm{r}^{2}=0.7302\right.$ and 0.7301$)$ while other two methods showed insignificant correlations (0.4-0.55). Insignificant correlations were found between antioxidant capacity with all three methods and anthocyanins content.

These results suggest that phenols, phenolic acids and proanthocyanidins are major contributors to the antioxidant capacity as the most abundant compounds in leaves and fruits. Similarly, strong correlations were found for total phenols and proanthocyanidins with ABTS and FRAP in callus extracts (BAHORUN ET AL., 1994), phenols, proanthocyanidins, phenolic acids in fruit extracts (RUIZ-RODRIGUEZ ET AL., 2014), phenols and proanthocyanidins with DPPH and FRAP in fruit extracts (MRAIHI ET AL., 2013).

Interestingly, although flavonoid content expressed as quercetin was much lower compered to rutin equivalents, correlation coefficients for antioxidant capacities and flavonoid contents expressed as quercetin or rutin equivalents were very similar for the same method. This is in agreement with observation of JUNG ET AL. (2007) that quercetin (flavonol aglicon) has stronger antioxidant activity as a result of presence multiple hydroxyl groups.

\section{CONCLUSION - Zaključak}

Leaf and fruit extracts of C. monogyna and C. $x$ macrocarpa were rich inphenolics, phenolic acids and proanthocyanidins.

Leaves of both species are richer in the content of phenols, flavonoids, phenolic acids and proanthocyanidins while fruits of both species are richer in content of monomeric anthocyanins.

C. $x$ macrocarpa leaves had higher contents of all investigated compounds than C. monogyna. On the other hand, C. monogyna fruit had higher content of total monomeric anthocyanins than C. $x$ macrocarpa fruit.

Leaves of both species had higher antioxidant activity than the fruits with all three methods. C. $x$ macrocarpa leaves and fruits had higher antioxidant activity than C. monogyna leaves and fruits.

Our results indicate that phenols including phenolic acids and proanthocyanidins are most probably the major contributors to the antioxidant properties of leaves and fruits extracts. This is supported by high correlation coefficients obtained between different method for antioxidant capacity and content of phenols, phenolic acids and proanthocyanidins in this work.

It can be concluded that both species especially $C . x$ macrocarpa, can be considered as a valuable source of antioxidant compounds. 


\section{REFERENCES - Literatura}

ABDENNACER, B., KARIM, M., YASSINE, M. NESRINE, R., MOUNA, D., MOHAMED, B. (2015): Determination of phytochemicals and antioxidant activity of methanol extracts obtained from the fruits and leaves of Tuniisian Lycium intricatum Boiss. Food Chemistry, 174, 577-584.

BAHORUN, T., TROTIN, F., POMMERY, J., VASSER, J., PINKAS, M. (1994): Antioxidant activities of Crataegus monogyna Extracts. Planta Medica, 60: 323328.

BAHRI-SAHLOUL, R., AMMAR, S., GREC, S., HARZALLAH-SKHIRI, F. (2009B): Chemical characterization of Crataegus azarolus L. fruit from 14 genotypes found in Tunisia. Journal of Horticulture Science of Biotechnology, 84, 23-28.

BARROS, L., CARVALHO, A.M., FERREIRA, I.C.F.R. (2010): Comparing the composition and bioactivity of Crataegus monogyna flowers and fruits used in folk medicine, Phytochemical Analysis. 22, 181-188.

BAŠıĆ, N. (2004): Morfološko-taksonomska istraživanja glogova (Crataegus L.) na području Bosne i Hercegovine. Magistarski rad. Sarajevo.

BECK, G. (1927): Flora Bosne, Hercegovine i oblasti Novoga Pazara. III. Choripetalae (Kaj): 169-172. Beograd-Sarajevo

BENZIE I.F. AND STRAIN J.J. (1999): The ferric reducing ability of plasma (FRAP) as a measure of "antioxidant power": the FRAP assay. Analytical Biochemistry, 239(1) 70-6.

BERKER, K.I.; GÜÇLÜ, K.; TOR, I.; APAK, R. (2007): Comparative Evaluation of $\mathrm{Fe}$ (III) Reducing PowerBased Antioxidant Capacity Assays in the Presence of Phenanthroline, Batho-phenanthroline, Tripyridyltriazine (FRAP), and Ferricyanide Reagents, Talanta, 72, 1157-1165.

BERNATONIENE, J., MASTEIKOVA, R., MAJIENE D., SAVICKAS, A., KEVELAITIS, E., BERNATONIENE, R., DVORAČKOVA, K., CIVINSKIENE, G., LEKAS, R., VITKEVIČIUS, K., PEČIURA, R. (2008): Free radical-scavenging activities of Crataegus monogyna extracts. Medicina (Kanaus), 44(9).

BRAND-WILLIAMS W, CUVELIER ME, BERSET C. (1995): Use of free radical method to evaluate antioxidant activity. Lebensm Wiss Technology, 28:25-30.

CHANG, Q., ZUO, Z., HARRISON, F., CHOW, M.S.S. (2002): Hawthorns: An overview of chemical, pharmacological and clinical studies. Journal of Clinical Pharmacology. 42, 605-612.

CHEN, J.H., AND HO, C.T. (1997): Antioxidant activity of caffeic acid and its related hydroxycinammic acid compounds. Journal of Agricultural Food Chemistry. 45, 2374-2378.

CHRIST, B. AND MULLER, K.H. (1960): Determination of the amount of flavonol derivates in drugs. Archiv der pharmazie, 293, 1033-1042. 
CHRISTENSEN, K. I. AND JANJIĆ, N. (2006): Taxonomic notes on European taxa of Crataegus (Rosaceae). Nordic Journal of Botany, 24: 143-147.

EDWARDS, J.E., BROWN, P.N., TALENT, N., DICKINSON, T.A., SHIPLEY, P.R. (2012): A review of the chemistry of the genus Crataegus. Phytochemistry, 79, 5-26.

EGEA, I., SANCEZ-BEL, P., ROMOJARO, F., PRETEL, MT. (2010): Six edible wild fruits as potential antioxidant additives or nutritional supplements. Plant Foods Human Nutrition 65:121-129.

FUKAREK, P. (1974): Neke vrste drveća i grmlja koje su pogrešno navedene u Flori Bosne i Hercegovine i susjednih krajeva. ANU BiH-Radovi LIV, Odjeljenje prirodno-matematičkih nauka, 15: 45-60.

GAWLIC-DZIKI, U. (2012): Dietary spices as natural effectors of lipoxygenase, xanthine oxidase, peroxidase and antioxidant agents. LTW-Food Science and Technology, 47, 138-146.

HAGERMAN, A.E. (2002): The Tannin Handbook. Miami University Oxford.

HARNAFI, H. AND AMRANI, S. (2008). Spectrophotometric methods for determination of plant polyphenols content and their antioxidant activity assessment: An Overview, Pharmacognosy Reviews, 2(3), 20-22.

HRABĔTOVÁ-UHROVÁ A. (1969): Hloh (Crataegus L.) v Československu. Preslia, (Praha). 41: 162-182.

JANJIĆ, N. (1998): Neki zanimljivi dendrološki nalazi iz sarajevskog područja. Radovi Šumarskog Fakulteta Univerziteta u Sarajevu, 28(1): 85-103.

JUNG, S.J., KIM, D.H., HONG, Y.H. (2007): Flavonoids from the flower of Rhododendron yedonese var. poukhanense and their antioxidant activities. Archives of Pharmacal Research, 30(2), 146:50.

KIM, S.H., KANG, K.W., KIM, K. W., KIM, N.D. (2000): Procyanidins in Crataegus extract evoke endothelium-dependent vasorelaxation in rat aorta. Life Science, 67:121-131.

LEE, J., DURST, RW., WROLSTAD, E. (2005): Determination of total monomeric anthocyanin pigment content of fruit juices, beverages, natural colorants, and wines by $\mathrm{pH}$ differential method: Collaborative study. Journal of AOAC International, 88(5), 1269-1278.

LIU, R.H., YU, B.Y., QIU, S.X., ZHENG, D. (2005): Comparative analysis of eight major polyphenolic compounds in leaves of Crataegus L. by HPLC. Chinese Journal of Natural Medicine, 3, 162-167.

MALÝ, K. (1919): Prilozi za floru Bosne i Hercegovine 5 i 6 . Glasnik Zemaljskog Muzeja BiH, Sarajevo, 31: 61-92.

MALÝ, K. (1940): Notizen zur Flora von Bosnien-Herzegovina. Glasnik Zemaljskog Muzeja BiH, Sarajevo, 52: 21-46. 
MANAH, C., SCALBERT, A, MORAND, C., REMESY, C., JIMENEZ, L. (2004): Polyphenols: food sources and bioavailability, The American Journal of Clinical Nutrition, 79:727-747.

MANDEL, S., AMIT, T., REZNICHENKO, L., WEINREB, O., YOUDIM, M-B. (2006): Green tea catechins as a brain permeable, natural iron chelators-antioxidants for the treatment of neurodegenerative disorders. Molecular Nutrition \& Food Research, 50, 229-34

MRAIHI, F., JOURNI, M., CHERIF, JK. SOKMEN, M., SOKMEN, A., TRABELSI-AYADI, M. (2013): Phenolic content and antioxidant potential of Crataegus fruits grown in Tunisia as determined by DPPH, FRAP, and $\beta$-carotene/linoleic acid assay. Journal of Chemistry, volume 2013, 1-6.

NAZ, S., SIDDIQI, R., AHMAD, S., RASOOL, S.A., SAYEED, S.A., (2007): Antibacterial activity directed isolation of compounds from Punica granatum. Journal of Food Science, 72, 341-345.

OLTHOF, M.R., HOLMAN, P.C.H., KATAN, M.B. (2001): Chlorogenic acid and caffeic acid are absorbed in human. Journal of Nutrion, 131, 66-71.

OSAWA, T. (1994): Novel natural antioxidants for utilization in food and biological systems in Postharvest Biochemistry of Plant Food-Materials in the Tropics, I. Uritani, V.V. Garcia, and E.M. Mendoza, Eds., 241-251, Japan Scientific Societies Press.

ÖZCAN, M., HACISEFEROGULLARY, H., MARAKOGLU, T., ARSLAN, D. (2005). Hawthorn (Crataegus spp) fruit: Some physical and chemical properties. Journal of Food Engineering, 69, 409-413.

ÖZYÜREK, M., BENER, M., GÜÇLÜ, K., DÖNMEZ, A.A., SÜZGEÇ-SELÇUK, S., PIRILDAR, S., MERIÇLI, A.H., APAK, R. (2012): Evaluation of antioxidant activity of Crataegus species collected from different regions of Turkey. Records of Natural Products, 6:3, 262-277.

RE R, PELLEGRINI N, PROTEgGENTE A, PANNALA A, YANG M, RICE-EVANS C.(1999): Antioxidant activity applying an improved ABTS radical cation decolorization assay.Free Radical Biology and Medicine, 26, (9-10), 1231-7.

RICE-EVANS, C.A., MILLER, N.J. (1997): Structure-antioxidant activity relationship of flavonoids and isoflavonoids. In: Ricde-Evans, C.A., packer, L. (Eds.), Flavonoids in Health and Disease. Marcel Dekker, New York.

RICE-EVANS, C.A., MILLER, N.J., BOLWELL, P.G., BRAMLEY, P.M., PRIDHAM, J.B. (1995): The relative antioxidant activities of plant-derived polyphenolic flavonoids. Free Radical Research, 22 (4), 375-383.

RUIZ-RODRIGEZ, B., DE ANCOS, B. SANCEZ-MORENO, C., FERNANDEZ-RUIZ, V., SANCEZ-MATA, M., CAMARA, M., TARDIO, J. (2014). Wild blackthorn (Prunus spinosa L.) and hawthorn (Crataegus monogyna Jacq.) as valuable source of antioxidants. Fruits, 69, 61-73. 
SEIFRIED, H. E., ANDERSON, D. E., FISHER, E. I. AND MiLNER, J. A. (2007). A review of the interaction among dietary antioxidants and reactive oxygen species. The Journal of Nutritional Biochemistry, 18 (9): 567-579.

SINGLETON, V.L., ORTHOFER, R., LAMUELA-RAVENTOS, R.M. (1974): Analysis of total phenols and other oxidation substrates and antioxidants by means of FolinCiocalteu reagent. Methods of Enzymology, 229, 152-178.

TAMPLE, N.J. (2000): Antioxidants and disease: more questions than answers. Nutrition Research, 20,449-459.

THAIPONG, K., BOONPRAKOB, U., CROSBY, K., CISNEROS-ZEVALLOS, L., BYRNE, D.H. (2006): Comparison of ABTS, DPPH, FRAP and ORAC assays for estimating antioxidant activity from guava fruit extracts. Journal of Food Composition and Analysis, 19, 669-675.

YU, L., HALEY, S., PERRET, J., HARRIS, M., WILSON, J., QIAN, M. (2002): Free radical scavenging properties of wheat extracts. Journal of Agricultural Food Chemistry, 50:1619-1624.

ZHANG, Z., CHANG, Q., ZHU, M., HUANG, Y., HO, W.K.K., CHEN, Z.-Y. (2001): Characterization of antioxidants present in hawthorn fruits. Journal of Nutritional Biochemistry, 12, 144.

\section{SAŽETAK}

Metanolni ekstrakti uzoraka lista i ploda C. monogyna Jacq i $C$. $x$ macrocarpa Hegetschw. analizirani su na sadržaj ukupnih fenola, flavonoida, fenolnih kiselina, monomernih antocijanina i proantocijanidina kao i antioksidacijsku aktivnost. U određivanju sadržaja bioaktivnih jedinjenja i antioksidacijske aktivnosti ekstrakata, korištene su spektrofotometrijske metode. Ukupni fenoli su određeni Folin-Ciocalteu metodom, a $\mathrm{AlCl}_{3}$ metodom vršeno je određivanje ukupnih flavonoida prema rutinu i kvercitinu kao standardima. Određivanje monomernih antocijanina izvršeno je primjenom $\mathrm{pH}$ diferencijalne metode a kiselinsko-butanolna metoda je upotrebljena za kvantifikaciju ukupnih proantocijanidina. Ukupne fenolne kiseline su određene Arnovom metodom. Za mjerenje antioksidacijske aktivnosti korištene su tri metode: DPPH, ABTS i FRAP metoda a rezultati su izraženi u ekvivalentima Troloxa po gramu suhog uzorka.

Sadržaji ukupnih fenola po gramu suhog uzorka (s.u) za uzorke listova kretali su se u području 59.23 - $91.91 \mathrm{mg} \mathrm{GAE} \mathrm{g}^{-1}$ s.u; ukupnih flavonoida $5.24-8.90 \mathrm{mg} \mathrm{RE} \mathrm{g}^{-1}$ s.u. i 2.38 - $4.08 \mathrm{mg} \mathrm{QE} \mathrm{g}^{-1}$ s.u; fenolnih kiselina 33.40 - $68.98 \mathrm{mg} \mathrm{CAE} \mathrm{g}^{-1}$; sadržaji

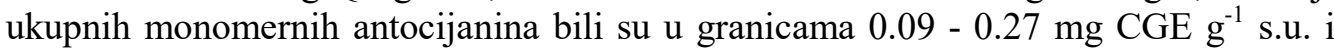
proantocijanidina 26.15 - $48.60 \mathrm{mg} \mathrm{CE} \mathrm{g}^{-1}$ s.u.

$\mathrm{U}$ uzorcima plodova sadržaji ispitivanih jedinjenja kretali su se $\mathrm{u}$ intervalima: ukupni fenoli 25.01 - $56.23 \mathrm{mg} \mathrm{GAE} \mathrm{g}^{-1}$ s.u; ukupni flavonoidi $0.72-1.81 \mathrm{mg} \mathrm{RE} \mathrm{g}^{-1}$ s.u i 0.31 - $0.85 \mathrm{mg} \mathrm{QE} \mathrm{g}^{-1}$ s.u; ukupne fenolne kiseline su bile $\mathrm{u}$ granicama 14.16 - $37.49 \mathrm{a}$ 
ukupni monomerni antocijanini $0.43-0.80 \mathrm{mg} \mathrm{CGE} \mathrm{g}^{-1} \mathrm{~s} . \mathrm{u}$; i ukupni proantocijanidini 12.00 - $21.84 \mathrm{mg} \mathrm{CE} \mathrm{g}^{-1}$ s.u.

Poređenjem prosječnog sadržaja aktivnih jedinjenja u listovima dvije vrste može se zaključiti C. $x$ macrocarpa ima veći prosječni sadržaj svih ispitivanih jedinjenja u odnosu na C. monogyna. Samo plodovi C. monogyna imaju veći prosječni sadržaj monomernih antocijana u odnosu na plodove C. $x$ macrocarpa.

Antioksidacijski kapacitet u listovima C. monogyna kretao se u području $0.34-0.51$ mmol Troloxa $\mathrm{g}^{-1}$ s.u., dok je u listovima C. $x$ macrocarpa bio u području $0.44-0.82$ mmol Troloxa $\mathrm{g}^{-1}$ s.u. Vrijednosti antioksidacijskog kapaciteta za plodove su iznosili $0.11-0.27$ mmol Troloxa $\mathrm{g}^{-1}$ s.u za C. monogyna i za C. $x$ macrocarpa $0.22-0.531$ mmol Troloxa ${ }^{-1}$ s.u.

Generalno, na osnovu prosječnih vrijednosti kapaciteta za sve tri metode može se zaključiti da listovi i plodovi C. $x$ macrocarpa imaju bolja antioksidacijska svojstva a što je u saglasnosti sa većim sadržajem aktivnih komponenti u ovoj vrsti.

Linearnom regresijom između sadržaja aktivnih komponenti i antioksidacijskog kapaciteta primjenom tri metode, određeni su koeficijenti korelacije $\left(\mathrm{r}^{2}\right)$. Utvrđeno je postojanje visoke korelacije između ukupnih fenola, fenolnih kiselina $\mathrm{i}$ proantocijanidina i antioksidacijskog kapaciteta $\left(\mathrm{AC}_{\mathrm{DPPH}}, \mathrm{AC}_{\mathrm{ABTS}}\right.$ i $\left.\mathrm{AC}_{\mathrm{FRAP}}\right)$.

Fenoli i proantocijanidini najbolje koreliraju sa FRAP metodom dok fenolne kiseline najbolje koreliraju sa ABTS metodom.

Na osnovu dobivenih rezultata se može zaključiti da je vrsta $C$. $x$ macrocarpa bogata u sadržaju antioksidacijskih aktivnih komponenti i kao takva je interesantna za detaljnija ispitivanja hemijskog sastava. 